\title{
ANALISIS TARIF JASA RAWAT INAP MENGGUNAKAN METODE ACTIVITY BASED COSTING (Studi Pada Puskesmas Sukarahayu Kabupaten Subang Tahun 2019)
}

\author{
Sarah Mutmainah \\ Universitas Padjadjaran - Bandung \\ Email : Sarah12032@mail.unpad.ac.id
}

\begin{abstract}
ABSTRAK
Pelayanan jasa kesehatan salah satu yang diminati sesuai dengan meningkatnya kebutuhan masyarakat terhadap jasa pelayanan kesehatan. Saat ini sudah banyak puskesmas milik pemerintah yang sudah tersebar di Indonesia. Puskesmas yang tersebar saat ini bergerak dalam bidang jasa pelayanan kesehatan. Semakin banyak bidang pelayanan kesehatan, maka semakin ketat persaingan jasa pelayanan kesehatan. Dalam memberikan jasa puskesmas memperoleh penghasilan dari pelayanan dan fasilitas yang diberikan salah satunya adalah jasa rawat inap, dalam menentukan tarif perlu mengetahui metode penetapan biaya berbasis aktivitas. Penentuan biaya berdasarkan kegiatan saat menentukan tarif yaitu Activity Based Costing (ABC). Dalam metode ABC, munculnya biaya diakibatkan oleh aktivitas yang dihasilkan. Penelitian ini bertujuan untuk mengetahui penentuan biaya pelayanan pasien rawat inap Puskesmas Sukarahayu. Metode analisis data yang di gunakan dalam penelitian ini menggunakan Analisis kuantitatif deskriptif. Berdasarkan hasil penelitian menunjukkan bahwa penentuan biaya pelayanan pasien rawat inap dengan menggunakan metode Activity Based Costing biaya pelayanan pasien rawat inap $R p$. 112.642,- penerapan tarif saat ini sebesar Rp. 162.000,- terdapat selisih sebesar Rp. 49.358,- dan kesimpulannya dalam menggunakan metode Activity Based Costing menunjukkan bahwa hasil yang diperoleh lebih rendah di bandingkan dengan tarif yang berlaku saat ini.
\end{abstract}

Kata Kunci: Activity Based Costing, Analisis Penentuan Biaya, tarif inap.

\section{PENDAHULUAN}

Kesehatan merupakan hak setiap orang, maka di butuhkan suatu entitas pelayanan kesehatan yang baik ini salah satu upaya pemerintah untuk mewujudkan hak warga negara untuk memperoleh kesehatan yang optimal adalah dibangunkan pelayanan kesehatan berupa puskesmas, baik daerah perkotaan dan pedesaan. Pelayanan jasa kesehatan salah satu yang diminati sesuai dengan meningkatnya kebutuhan masyarakat terhadap jasa pelayanan kesehatan. Saat ini sudah banyak puskesmas milik pemerintah yang sudah tersebar di Indonesia. Puskesmas yang tersebar saat ini bergerak dalam bidang jasa pelayanan kesehatan. Semakin banyak bidang pelayanan kesehatan, maka semakin ketat persaingan jasa pelayanan kesehatan atau jasa medis. (Zakhra \& Khusairi, 2019).

Puskesmas saat ini masih memiliki banyak keterbatasan dan kekurangan terutama inovasi dan pengembangan pelayanan antara sarana dan prasarana, pelayanan kesehatan dibawah standar pelayanan minimal, belum didukung sistem informasi kesehatan terkini, dan kesejahteraan tenaga medis yang kurang diperhatikan. (Ali et al., 2018). Permasalahan tersebut tidak terlepas dari rencana alokasi biaya. Agar dapat bertahan puskesmas harus mampu meningkatkan kualitas pelayanan kepada masyarakat. Tugas utama puskesmas adalah memberikan pelayanan medis, keperawatan, dan layanan kesehatan. Dalam memberikan jasa puskesmas memperoleh penghasilan dari pelayanan dan fasilitas yang diberikan salah satunya adalah jasa rawat inap, dimana penghasilan pelayanan tersebut berasal dari tarif yang harus dibayar pengguna jasa rawat inap. Untuk mencapai hal tersebut, Puskesmas dituntut untuk bisa menjalankan kebutuhan operasional dengan efisien sesuai fungsi yang dilakukan agar tujuannya tercapai.

Tingkat persaingan yang tinggi diperlukan strategi yang dapat memenangkan persaingan dengan menekan nilai jual. Semakin rendah harganya, semakin tinggi tingkat penjualan tersebut. Dalam rangka pengendalian biaya, puskesmas memerlukan penghitungan biaya penentuan, untuk menghasilkan informasi biaya yang akurat untuk menentukan tarif diperlukan informasi biaya dan 
analisis biaya yang sistematis dan komparatif. Misalnya konsultasi, pemeriksaan kesehatan, pemeriksaan komposisi kesehatan tubuh. Untuk menyediakan layanan ini langsung digunakan dan dirasakan oleh klien. Misalnya tenaga medis, peralatan kesehatan, obat-obatan, dan lain-lain yang sebagian tidak langsung digunakan oleh pelanggan, tetapi sangat dibutuhkan untuk kelancaran pelayanan, seperti: gedung, alat tulis kantor, peralatan kesehatan, listrik, air, dan jaringan pelayanan kesehatan. (Gondodiputro, 2015).

Sumber Informasi membantu pemerintah daerah untuk menentukan tarif atau pengeluaran puskesmas untuk mengevaluasi, menunjukan keberhasilan atau kegagalan tanggung jawab pemeliharaan khusus berbagai macam fasilitas untuk layanan rawat inap, Dan biaya yang dikeluarkan. Hal tersebut belum termasuk dalam pengajuan rutin, maka harus dipertimbangkan pembebanan biaya yang seharusnya, sehingga dalam menentukan biaya, pemerintah daerah memperhatikan biaya yang seharusnya terbebankan pada pelayanan. Oleh karena itu, dalam menentukan tarif, pemerintah daerah perlu mengetahui metode penetapan biaya berbasis aktivitas, yaitu penentuan biaya berdasarkan kegiatan saat menentukan tarif, hal ini menunjukkan bahwa pemerintah telah menyadari pentingnya perhitungan harga pokok termasuk pelayanan kesehatan. Dengan kemajuan ilmu pengetahuan, tujuan mengatasi distorsi biaya adalah menciptakan sistem penentuan harga pokok berdasarkan aktivitas.

Sistem akuntansi ini yaitu Activity based costing (ABC). Dalam metode $\mathrm{ABC}$, munculnya biaya diakibatkan oleh aktivitas yang dihasilkan. Menurut (Mowen, 2004) pada kegiatan yang menimbulkan biaya dengan menggunakan cost driver akan lebih baik apabila diterapkan. Di samping itu, sesuai dengan biaya yang dihasilkan akan membagikan informasi biaya produksi yang terdistorsi ialah under costing ataupun over costing. Distorsi yang akan mengakibatkan kesalahan pengambilan keputusan serta kelangsungan organisasi. Sehingga butuh diterapkannya sistem penentuan harga pokok bersumber pada aktivitasnya (activity based) ataupun lebih diketahui dengan nama Activity Based Costing System.

Activity Based Costing System ialah suatu sistem informasi akuntansi yang mengidentifikasikan beragam kegiatan yang dikerjakan di dalam sesuatu organisasi serta mengumpulkan biaya dengan dasar sifat yang terdapat dari kegiatan tersebut. Analisis biaya dengan cara menelusuri aktifitas selaku pemicu pengeluaran inilah dalam akuntansi biaya. Prosedur ABC (Activity Based Costing) sangat efisien digunakan dalam penentuan tarif inap, disebabkan activity based costing ialah suatu pembebanan pengeluaran yang membebankan pengeluaran bersumber pada kegiatan yang dikerjakan dalam sesuatu organisasi serta mengumpulkan pengeluaran bersumber pada sikap yang terdapat dari kegiatan yang dilakukan untuk memastikan harga jasa layanan inap.

Terdapat beberapa penelitian terkait dengan perhitungan tarif jasa dengan menggunakan metode Activity Based Costing (ABC) diantaranya penelitian yang dilakukan (Sabijono \& Panekenan, 2014) mengenai Penerapan Metode Activity Based Costing dalam menentukan besarnya tarif jasa inap pada penginapan vili calaca manado hasil penelitian menunjukan terdapat selisih antara harga jual penginapan dan harga jual $\mathrm{ABC}$, dimana perhitungan $\mathrm{ABC}$ memberikan hasil lebih kecil dari harga jual yang ditetapkan oleh pihak penginapan. Menurut (Zakhra \& Khusairi, 2019) dalam penelitiannya mengenai Analisis Penentuan Biaya Pelayanan Pasien Rawat Inap Pada Puskesmas Palengaan Pamekasan dalam penelitiannya menunjukan bahwa penentuan biaya pelayanan pasien rawat inap dengan menggunakan metode $\mathrm{ABC}$ hasil yang diperoleh lebih tinggi dibandingkan dengan tarif yang berlaku saat ini.

Berdasarkan fenomena, teori serta penelitian terdahulu yang diuraikan diatas dapat di simpulkan yaitu dengan menggunakan metode Activity Based Costing (ABC) yang sudah dilakukan namun hasil dari tarif jasa tersebut masih adanya ketidak konsistenan. Sehingga harus memiliki dukungan yang baik dari segi sumber daya manusia dan teknologi. Untuk itu penelitian kali ini peneliti ingin lebih mengetahui lebih jauh karena puskesmas sebagai salah satu fasilitas kesehatan puskesmas berperan menyelenggarakan sebagian dari tugas teknis operasional Dinas Kesehatan Kabupaten/Kota dan merupakan unit pelaksana tingkat pertama serta ujung tombak pembangunan kesehatan di Indonesia dan meningkatkan kesadaran, kemauan dan kemampuan hidup sehat bagi setiap orang agar terwujud derajat kesehatan masyarakat yang optimal.

Tujuan dalam penelitian ini adalah untuk menghitung biaya pelayanan pasien yang diperlukan dan perhitungan untuk menentukan harga rawat inap berdasarkan aktivitas. Metode ini disebut Activity Based Costing (ABC). Activity Based Costing adalah suatu sistem akuntansi yang terfokus 
pada aktivitas-aktivitas yang dilakukan untuk menghasilkan produk atau jasa. Aktivitas adalah setiap kegiatan atau transaksi yang mana akvititas ini timbulnya pemicu biaya (cost driver). Dengan menghitung tarif tersebut apakah tarif yang ditentukan dapat menjadi pembanding dengan tarif yang sudah berlaku. Metode Activity Based Costing juga melengkapi keakuratan perhitungan harga pokok produk dengan menjelaskan bahwa banyak dari biaya overhead tetap bervariasi dalam kegiatan aktivitas. Metode $\mathrm{ABC}$ difokuskan pada kegiatan, yaitu apa saja yang dilakukan oleh tenaga kerja dan peralatan untuk memenuhi kebutuhan pelanggan yang mana kegiatan tersebut menimbulkan biaya.

Hasil dari penelitian ini, diharapkan mampu menjadi bahan evaluasi dan pertimbangan untuk pengambilan keputusan sehingga penentuan tarif lebih efektif. Dengan adanya Activity Based Costing bisa sediakan data perhitungan biaya serta bisa menolong mengelola secara efektif dan mendapatkan penjelasan yang lebih baik atas keunggulan kompetitif. Sehingga dengan metode Activity Based Costing bisa menyajikan data harga pokok produk ataupun jasa secara teliti serta akurat untuk kepentingan manajemen. Konsep sistem Activity Based Costing ialah alternatif pemecahan yang ditempuh buat memperoleh data akuntansi yang relevan dalam keragaman keadaan serta sistem $\mathrm{ABC}$ ini bisa diterapkan pada puskesmas pastinya disesuaikan dengan suasana serta keadaan yang cocok dengan pertumbuhan manajemen merupakan analisis biaya dengan metode activity based costing ( $\mathrm{ABC}$ ). Dari analisis biaya dengan metode Activity Based Costing ini diharapkan dapat ditetapkan pengeluaran satuan (unit cost) di puskesmas sukarayu subang yang diperlukan. Berikutnya dapat digunakan untuk acuan menetapkan pengeluaran di puskesmas.

\section{KAJIAN PUSTAKA Konsep Akuntansi}

Akuntansi mempunyai peranan yang sangat besar selaku instrument pembantu dalam pengambilan keputusan-keputusan ekonomi. Untuk dunia usaha, akuntansi sangat diperlukan melancarkan tugas manajemen, dalam melakukan perencanaan serta pengawasan. Oleh karena itu akuntansi banyak dipelajari oleh para usahawan. Definisi akuntansi menurut (Horngren, Datar, Foster, 2013) mengatakan akuntansi merupakan sistem data yang mengukur bisnis, memproses informasi jadi laporan serta mengkomunikasikan hasilnya kepada pengambil keputusan. Akuntansi merupakan sistem data yang mengukur kegiatan bisnis, memproses data jadi laporan keuangan. Serta mengkomunikasikan hasilnya kepada para pembuat keputusan.

Akuntansi keuangan sediakan data keuangan untuk pihak ekternal yang mebutuhkan semacam investor, kreditor, pemerintah dah pihak yang lain. Sebaliknya akuntansi manajeman ialah sistem perlengkapan, merupakan kategori data yang dihasilkannya diperuntukan kepada pihak- pihak internal organisasi, semacam manajer keuangan, manajer produksi, manajer pemasaran serta sebagainya guna pengambilan keputusan internal organisasi dengan melaksanakan serta mengatur dalam menggapai tujuannya. (Mulyadi, 2001)

Akuntansi biaya bukanlah jenis akuntansi yang independen terpisah dari kedua tipe tersebut. Namun merupakan bagian dari keduanya. Fokus utama dari akuntansi biaya yaitu akumulasi dan analisis informasi yang relavan ketika manajer secara sistematis memantau dan mencatat transaksi biaya dan menyajikan informasi biaya dalam bentuk laporan biaya. (Mulyadi, 2001)

\section{Akuntansi Biaya}

Menurut (Mulyadi, 2009) akuntansi biaya adalah proses pencatatan, pengelompokan, peringkasan dan penyajian biaya, pembuatan dan penjualan produk atau jasa dengan cara tertentu, dan menginterpretasikannya. (Mulyadi, 2009) Penetapan biaya adalah tentang mengumpulkan, menyajikan dan menganalisis informasi biaya-manfaat, membantu manajemen untuk mempresentasikan tugas - tugas berikut: yaitu membantu dan melaksanakan rencana dan anggaran untuk beroperasi di bawah kondisi persaingan dan ekonomi yang ditingkatkan sebelumnya. Dan ditetapkan metode penetapan biaya yang memungkinkan untuk mengontrol aktivitas, mengurangi biaya, dan meningkatkan kualitas. Kontrol kualitas fisik inventaris dan menetukan biaya setiap produk dan layanan yang diproduksi serta menentukan harga dan evaluasi kinerja produk, departemen atau devisi. 
Menurut (Wensen et al., 2016) Akuntansi biaya adalah proses pencatatan, penggolongan, peringkasan, dan penyajian biaya produksi, penjualan produk atau penyediaan jasa dan menafsirkannya berkaitan dengan hasil. Akuntansi biaya menyediakan informasi akuntansi manajemen dan akuntansi keuangan yang diperlukan. Pengukuran Akuntansi dan melaporkan informasi keuangan dan non keuangan yang terkait dengan biaya perolehan atau pemanfaatan sumber daya dalam organisasi (Datar \& Rajan, 2017). Dapat disimpulkan dari beberapa definisi bahwa akuntansi biaya adalah suatu proses pencatatan, pengklasifikasi, perhitungan, penyajian, dan penganalisaan biaya produksi yang digunakan hanya untuk keperluan intern saja.

\section{Konsep Biaya}

(Charter \& Milton F, 2006) mendefinisikan biaya sebagai nilai tukar, pengeluaran, pengorbanan untuk mendapatkan keuntungan. Dalam akuntansi keuangan, pengeluaran atau pengorbanan pada saat pembelian dinyatakan sebagai penyusutan saat ini atau masa depan dalam bentuk uang tunai atau aset lainnya. (Mulyadi, 2001) menunjukan bahwa biaya merupakan subjek akuntansi biaya. Secara garis besar. Biaya adalah kas atau nilai setara kas yang dikorbankan untuk memperoleh barang atau jasa yang diharapkan dapat memberikan manfaat saat ini atau di masa depan bagi organisasi(Hansen \& Mowen, 2006). Menurut (Krismiaji, 2015) menyatakan bahwa biaya adalah kas atau setara kas yang dikorbankan untuk membeli barang atau jasa yang diharapkan dapat membawa keuntungan bagi perusahaan sekarang atau dimasa yang akan datang. Dapat diuraikan dari definisi sebagai berikut. Biaya (cost) adalah sumber daya ekonomi yang diukur dalam satuan uang yang telah terjadi atau mungkin terjadi dimasa yang akan datang.

\section{Penggolongan Biaya}

Ada beberapa kategori dalam akuntansi biaya. Klasifikasi adalah proses pengelompokan secara sistematis semua elemen menjadi beberapa kelompok yang lebih ringkas untuk memberikan informasi penting. Jenis biaya akan dijelaskan di bawah ini berdasarkan klasifikasi. Menurut (Mulyadi, 2001) biaya dapat diklasifikasikan menurut metode sebagai berikut: Pertama, pengklasifikasian biaya menurut objek pengeluaran menjadi dasar untuk mengklasifikasikan biaya, diantaranya: yang pertama biaya bahan baku merupakan bahan yang membentuk bagian menyeluruh produk jadi. Bahan baku yang digunakan proses pembuatan umumnya dikelompokkan atas bahan baku langsung serta bahan baku tidak langsung ataupun bahan penolong. Pertimbangan utama dalam pengelompokkan bahan baku ini merupakan penelusuran bahan sampai dengan barang jadi. Bahan baku langsung ialah totalitas bahan baku yang diolah jadi barang jadi serta bisa digunakan langsung pada harga pokok dari barang jadi, ataupun dengan kata lain ialah komponen biaya yang jumlahnya relatif besar dalam menciptakan output serta umumnya ialah bagian integral dari output tersebut. Yang kedua Bahan baku tidak langsung disebut juga biaya bahan penolong, yaitu bahan baku yang jumlahnya relatif kecil untuk menghasilkan produk. Yang ketiga Biaya tenaga kerja langsung, Biaya tenaga kerja adalah harga yang dibebankan untuk penggunaan tenaga kerja manusia tersebut. Biaya tenaga kerja berdasarkan fungsi produksi diklasifikasikan atas biaya tenaga kerja langsung serta biaya tenaga kerja tidak langsung. terakhir biaya overhead adalah keseluruhan biaya yang terjadi pada departemen produksi selain biaya bahan langsung dan biaya tenaga kerja langsung. Adapun yang termasuk biaya tidak langsung ialah Biaya overhead pabrik yang masuk dalam biaya ini ialah biaya listrik, biaya air dan biaya telepon. Secara umum biaya overhead dibedakan menjadi biaya overhead tetap yaitu biaya overhead pabrik yang jumlahnya tetap walaupun volume produksinya bervariasi dan biaya overhead variabel yaitu biaya overhead pabrik yang berubah sesuai dengan perubahan volume produksi.

\section{Activity Based Costing (ABC)}

Pengertian Activity Based Costing (Mcgraw-hill, 2012) mendefenisikan "activity based costing adalah sistem perhitungan harga pokok produksi yang dirancang untuk menyediakan informasi biaya bagi manajer untuk pembuatan keputusan strategi dan keputusan lain yang mempengaruhi kapasitas dan biaya tetap". Menurut (Hansen \& Mowen, 2006) sistem biaya berdasarkan aktivitas (Activity Based Cost - ABC) biaya aktivitas harus dicari terlebih dahulu dan kemudian produk asumsi dasarnya adalah bahwa aktivitas menggunakan sumber daya dan produk sebagai gantinya memakai aktivitas akan tetapi dalam sistem biaya $\mathrm{ABC}$ menekankan penelusuran 
langsung dan penelusuran penggerak (menekankan hubungan sebab akibat). Berikut ini adalah proses yang harus diselesaikan ketika menerapkan penetapan biaya berbasis aktivitas (a) Proses tahap pertama. Pada tahap pertama, penentuan harga pokok berdasarkan aktivitas meliputi empat langkah berikut: (1) Klasifikasi berbagai aktivitas. (2) Hubungkan biaya dan aktivitas. (3) Menentukan alokasi biaya yang homogen, dan (4) Menentukan tarif alokasi.

Sedangkan menurut definisi activity-based costing (ABC) merupakan salah satu metode kontemporer yang dibutuhkan oleh manajemen modern untuk meningkatkan kualitas dan efisiensi, menghilangkan waktu operasi yang tidak menambah nilai, menambah biaya dan meningkatkan kendali atas hasil perusahaan. Menurut (Sumamora, 2012) biaya komoditas berbasis aset adalah sistem akuntansi yang berfokus pada aktivitas yang dilakukan untuk menghasilkan produk atau jasa. Sistem penetapan biaya aktivitas memberikan informasi tentang aktivitas dan sumber daya yang diperlukan untuk melaksanakannya. Beberapa langkah penting dalam mengimplementasikan sistem penetapan biaya kegiatan meliputi: 1) Mengidentifikasi kegiatan serupa 2) Mengidentifikasi pusat kegiatan 3) Mengidentifikasi faktor biaya 4) Menghitung fungsi biaya untuk menghubungkan biaya dan faktor biaya dengan sumber daya 5) Menetapkan biaya ke objek biaya - ini sering adalah biaya produk. Biaya item berbasis sumber daya (ABC) adalah sistem akuntansi biaya di mana lebih dari satu tempat penampungan dialokasikan atas dasar yang mencakup satu atau lebih faktor non-volume (faktor non-volumetrik).

\section{Kelemahan dan Keunggulan Activity based Costing}

Menurut (Garison, Noren, 2013) Kelemahan ABC adalah laporan yang dihasilkan oleh sistem $\mathrm{ABC}$ yang paling baik tidak akan cocok dengan akuntansi keuangan yang berlaku. Oleh karena itu, organisasi yang menggunakan $\mathrm{ABC}$ harus memiliki dua sistem biaya yang berbeda, satu untuk pengguna internal dan satu lagi untuk pelaporan eksternal. Padahal keuntungannya adalah bisa mengambil keputusan. Kelemahan dari ABC tidak menyajikan biaya yang dapat dihindari dengan berhenti memproduksi produk dengan lebih banyak. Di sisi lain, keuntungannya adalah menyediakan informasi biaya yang lebih andal, dan hosting yang digerakkan oleh manajemen akan dapat memberikan penawaran kompetitif yang lebih adil.

\section{Metode Activity Based Costing}

Menurut (Garison, Noren, 2013) Saat menghitung biaya usaha, yaitu 1) Biaya non produksi dalam akuntansi biaya tradisional hanya biaya produksi yang dialokasikan untuk produk. Biaya penjualan, umum dan administrasi diperlukan sebagai biaya berulang dan tidak dialokasikan ke produk. Sebagian dari biaya non produksi tersebut juga merupakan bagian dari biaya produksi, penjualan, pendistribusian dan servis produk. Dalam hal ini, istilah tersebut digunakan untuk menggambarkan biaya non-produk dan biaya langsung. Di ABC, produk dibebankan dengan semua biaya overhead, biaya non-produksi dan biaya produksi langsung yang disebabkan oleh produk tersebut. 2) Biaya produksi dan penetapan biaya berbasis aktivitas Biaya berbasis aktivitas, produk dibebankan hanya untuk kapasitas yang digunakan, bukan untuk biaya kapasitas yang tidak terpakai. 3 ) Penetapan biaya, dasar alokasi dan penetapan biaya berdasarkan aktivitas kumpulan adalah wadah untuk mengakumulasi biaya yang sesuai dengan pengukuran aktivitas tunggal dalam sistem ABC.

Langkah pertama pada tahap pertama proses $\mathrm{ABC}$ adalah mengklasifikasikan aktivitas. Kegiatan dibagi ke dalam kelompok yang memiliki penjelasan fisik yang sederhana dan jelas serta sesuai untuk bagian proses produksi yang dapat dikelola. Setelah mengkategorikan berbagai aktivitas, langkah kedua adalah mengaitkan berbagai biaya dengan setiap aktivitas. Selanjutnya, langkah ketiga adalah menentukan kelompok homogen dari kelompok biaya yang ditentukan. Kelompok biaya yang sama Kumpulan biaya yang sama adalah kumpulan biaya tidak langsung dan tugas-tugas yang terkait secara logis yang akan dilakukan Berbagai biaya dapat dijelaskan oleh satu pemicu biaya. Dengan kata lain, jika aktivitas overhead dapat dihubungkan secara logis dan tingkat konsumsi semua produk sama, maka sekumpulan biaya dapat dikatakan homogen. Tingkat konsumsi yang sama menunjukkan adanya cost driver. Penggerak biaya yang dipilih harus mudah dipahami, terkait langsung dengan aktivitas yang dilakukan, dan memadai untuk pengukuran kinerja. Jika kelompok biaya yang sama ditentukan, langkah terakhir adalah menetapkan tarif kelompok. Tingkat konsolidasi adalah tingkat pengeluaran tidak langsung per unit pemicu biaya. Ini dihitung 
untuk sekelompok aktivitas. Biaya unit suatu produk dihitung dengan menambahkan total biaya produk utama ke biaya tidak langsung yang telah dikumpulkan, dan kemudian membagi biaya total dengan unit yang diproduksi.

Hal yang perlu diperhatikan (Mulyadi, 2001) dalam melakukan penentuan cost driver adalah pengidentifikasian aktivitas pada berbagai tingkat. Pada proses ini aktivitas yang luas dikelompokkan ke dalam empat kategori aktivitas, yaitu: Aktivitas-aktivitas berlevel unit (unit level activities). Aktivitas yang dilakukan setiap satu kali unit produk diproduksi, besar kecilnya aktivitas ini dipengaruhi oleh jumlah unit produk yang diproduksi. untuk masingmasing output yang diproduksi. Aktivitas-aktivitas berlevel batch (batch level activities) Aktivitas yang dilakukan setiap kali suatu batch produk diproduksi, besar kecilnya aktivitas ini dipengaruhi oleh jumlah batch produk yang diproduksi. Aktivitas -aktivitas berlevel produk (product level activities) Aktivitas yang dilakukan untuk mendukung berbagai produk yang diproduksi oleh perusahaan. Aktivitas ini menggunakan masukan (input) yang bertujuan untuk mengembangkan dan atau memproduksi produk untuk dijual. Biaya dari aktivitas jenis ini cenderung meningkat seiring dengan meningkatnya jumlah produk yang berbeda. Aktivitas-aktivitas berlevel fasilitas (facility level activities) Aktivitas-aktivitas yang dilakukan untuk mempertahankan proses produksi secara keseluruhan. Aktivitas ini tidak berhubungan dengan volume atau bauran produk yang diproduksi dan dimanfaatkan secara bersama oleh berbagai jenis produk yang berbeda. Aktivitas ini memberikan keuntungan bagi organisasi sampai tingkat tertentu, akan tetapi tidak memberikan keuntungan untuk satu spesifik produk. (b) Prosedur tahap kedua. Di dalam tahap yang kedua, biaya-biaya dari setiap overhead pool ditelusuri kembali ke hasil produksi.

Hal yang perlu diperhatikan dalam menentukan cost driver (Mulyadi, 2001) adalah menentukan aktivitas pada setiap level. Dalam proses ini, luas kegiatan dibagi menjadi empat kategori kegiatan, yaitu: kegiatan tingkat unit. Aktivitas yang dilakukan setiap kali satu unit produk diproduksi Besarnya aktivitas ini dipengaruhi oleh banyaknya unit produk yang diproduksi. Untuk setiap keluaran yang dihasilkan. Aktivitas tingkat batch Setiap kali satu batch produk diproduksi, ukuran aktivitas ini akan dipengaruhi oleh jumlah batch produk yang diproduksi. Aktivitas level produk adalah aktivitas yang dilakukan untuk mendukung berbagai produk yang dihasilkan oleh perusahaan. Kegiatan ini menggunakan input yang dirancang untuk mengembangkan atau menghasilkan produk yang akan dijual. Dengan meningkatnya jumlah produk yang berbeda, biaya aktivitas ini cenderung meningkat. Aktivitas tingkat fasilitas adalah aktivitas untuk mempertahankan seluruh proses produksi. Kegiatan ini tidak ada hubungannya dengan kuantitas atau campuran produk yang diproduksi bersama dan digunakan oleh berbagai jenis produk. Aktivitas ini membawa manfaat bagi organisasi sampai batas tertentu, tetapi tidak membawa manfaat bagi produk tertentu. (B) Prosedur tahap kedua. Pada tahap kedua, biaya setiap overhead dapat ditelusuri Kembali dari hasil produksi.

\section{Sistem Biaya Tradisional}

Perbandingan biaya produk tradisional dan metode biaya aktivitas Jika tenaga kerja langsung dan bahan baku merupakan faktor utama dalam produksi, sistem yang menggunakan metode konvensional berdasarkan kuantitas untuk menentukan biaya produk sangat berguna. Sistem yang menggunakan metode konvensional untuk menentukan biaya produk mengasumsikan semua biaya dibagi menjadi biaya tetap atau biaya variabel berdasarkan perubahan unit atau kuantitas produk yang dihasilkan, sehingga unit produk atau motivasi lain sangat erat kaitannya dengan unit produksi, seperti waktu kerja langsung atau jam mesin. Inilah satu-satunya motif yang dianggap penting. Oleh karena itu, banyak alokasi biaya produk yang harus diklasifikasikan sebagai alokasi.

Berdasarkan penjelasan di atas, biaya bahan baku dan biaya tenaga kerja langsung disebut juga biaya utama, sedangkan biaya tenaga kerja langsung dan biaya tidak langsung perusahaan biasa disebut biaya konversi, yaitu biaya konversi atau penggantian bahan. Belum diolah menjadi produk jadi. Overhead pabrik adalah biaya material tidak langsung, pekerja tidak langsung, dan semua biaya perusahaan lainnya yang tidak dapat langsung dimasukkan ke dalam produk tertentu. Secara sederhana dapat dikatakan bahwa overhead perusahaan mencakup seluruh biaya perusahaan, kecuali biaya yang dicatat sebagai biaya langsung yaitu bahan langsung dan pekerja langsung. Bahan langsung adalah semua bahan yang merupakan bagian tidak terpisahkan dari produk jadi dan dapat langsung dimasukkan ke dalam penghitungan biaya produk. Pertimbangan utama dalam 
mengklasifikasikan bahan bagaikan bahan langsung yakni kemudahan melacak proses pengubahan bahan tersebut sebagai produk jadi. Tenaga kerja langsung mengacu pada karyawan yang mengubah bahan langsung menjadi produk jadi. Biaya ini termasuk gaji karyawan perusahaan yang dapat dipotong dari produk tertentu. Akuntansi biaya konvensional (tradisional) memiliki pro dan kontra. Keuntungan akuntansi biaya konvensional adalah sebagai berikut. Pertama, mudah diterapkan. Sistem akuntansi biaya tradisional tidak menggunakan banyak faktor pendorong biaya ketika mengalokasikan biaya produksi tidak langsung, sehingga manajemen dapat melakukan perhitungan dengan lebih mudah. Kedua, mudah untuk ditinjau. biaya produksi tidak langsung dialokasikan berdasarkan pada volume, sehingga mempermudah auditor dalam melaksanakan proses audit. Kerugian dari sistem akuntansi biaya tradisional ini adalah sebagai berikut. Ketiga, biaya produk bisa terdistorsi. Beberapa penyebab distorsi biaya adalah sebagai berikut. Biaya tidak langsung tidak akan ditelusuri kembali ke produk secara terpisah. Total komponen overhead dalam biaya produksi terus meningkat. Ketika persentase biaya tidak langsung besar, distorsi biaya produk juga akan besar. Banyak aktivitas yang termasuk dalam penjualan aktual dan biaya manajemen dapat ditelusuri kembali ke produk. Posisi fungsi keempat. Biaya diakumulasikan oleh fungsi-fungsi seperti proyek (teknik di setiap proyek).

\section{METODE PENELITIAN \\ Jenis Penelitian}

Penelitian yang dilakukan menggunakan jenis penelitian deskriptif dengan pendekatan studi kasus. Penelitian deskriptif bertujuan untuk membuat deskripsi secara sistematis, akurat, dan faktual mengenai fakta-fakta dan sifat-sifat objek tertentu. Adapun penelitian ini bertujuan untuk mempelajari secara intensif mengenai kalkulasi biaya berdasrkan aktivitas. Menurut (Uma Sekaran \& Bougie , 2013) penelitian deskriftif adalah jenis penelitian konklusif yang memiliki tujuan utama untuk mendeskrifsikan sesuatu biasanya penjelasan mengenai karakteristik pasar atau fungsi.

\section{Teknik pengumpulan data}

Teknik pengumpulan data yang digunakan pada penelitian ini adalah dokumentasi. Dokumentasi merupakan teknik pengumpulan data yang dilakukan peneliti dengan cara mengumpulkan data, catatan-catatan, dan dokumen-dokumen yang relevan dengan kebutuhan penelitian untuk kemudian diolah sebagai bahan penelitian. Yang didokumentasikan yaitu tarif rawat inap, biaya rawat inap, data pendukung lama harian pasien rawat inap, data pendukung jumlah pasien rawat inap, data pendukung luas ruangan inap, dan tenaga listrik.

\section{Definisi operasional variabel}

Operasional penelitian merupakan definisi yang diberikan terhadap variabel yang diteliti dengan cara memberikan definisi terhadap istilah tersebut serta bagaimana tabel tersebut diukur :

Tabel 1 Operasional Variabel

\begin{tabular}{|c|c|c|}
\hline Istilah & Definisi operasional & Indikator \\
\hline $\begin{array}{lr}\text { Metode } & \text { Activity } \\
\text { Based Costing (ABC) }\end{array}$ & $\begin{array}{l}\text { Suatu sistem yang pertama kali menelusuri biaya } \\
\text { ke aktivitas yang menyebabkan biaya tersebut dan } \\
\text { membebankan biaya aktivitas kepada produk }\end{array}$ & $\begin{array}{l}\text { Actvity } \quad \text { Based } \\
\text { Costing : } \\
\text { Cost Driver } \\
\end{array}$ \\
\hline Tarif & $\begin{array}{l}\text { Beban biaya yang tidak langsung yang ditentukan } \\
\text { terlebih dahulu untuk setiap penggunanya }\end{array}$ & $\begin{array}{l}\text { Laporan } \\
\text { inap }\end{array}$ \\
\hline
\end{tabular}

Sumber: (Krismiaji, 2015)

\section{Teknik Analisis data}

Peneliti menggunakan Teknik analisis kuantitatif sebagai alat dalam membantu memecahkan masalah- masalah peneliti. Menurut (Mowen, 2004) dalam metode Activite Based Costing menentukan tarif atau unit pemicu biaya (cost driver) dapat dihitung dengan rumus sebagai berikut :

$$
\text { Tarif Per Unit Cost Driver }=\frac{\text { Jumlah Aktivitas }}{\text { Cost Driver }}
$$




\section{HASIL DAN PEMBAHASAN}

\section{Hasil Penelitian}

Kunjungan rawat inap pasien tahun 2019. Dapat dilihat pada tabel sebagai berikut.

Tabel 2 Jumlah Pasien Rawat Inap Puskesmas Sukarahayu Subang Tahun 2019.

\begin{tabular}{|l|c|c|c|}
\hline Bulan & Laki-laki & Perempuan & Jumlah Pasien \\
\hline Januari & 26 & 47 & 73 \\
\hline Februari & 33 & 62 & 95 \\
\hline Maret & 30 & 46 & 76 \\
\hline April & 28 & 46 & 74 \\
\hline Mei & 38 & 39 & 77 \\
\hline Juni & 9 & 45 & 54 \\
\hline Juli & 15 & 21 & 36 \\
\hline Agustus & 31 & 30 & 61 \\
\hline September & 41 & 43 & 84 \\
\hline Oktober & 21 & 26 & 47 \\
\hline November & 15 & 0 & 15 \\
\hline Desember & 16 & 29 & 45 \\
\hline \multicolumn{5}{|c|}{ Total } & 737 \\
\hline
\end{tabular}

Sumber: Puskesmas Sukarahayu Subang

Tabel 2 menunjukan data pengunjung puskesmas selama tahun 2019. Berdasarkan data yang dapat dilihat bahwa jumlah pasien laki-laki dan perempuan setiap bulannya berada diatas 30 orang pasien. Jumlah terkecil berada pada bulan November 2019 dengan jumlah pasien sebesar 15 orang. Sementara itu pasien terbanyak pada bulan Februari 2019 dengan jumlah pasien sebesar 95 orang. Total kunjungan dari keseluruhan pasien tahun 2019 laki-laki dan perempuan sebesar 737 orang pasien.

Tabel 3 Perhitungan Tarif Rawat Inap Menggunakan Metode Activity Based Costing Puskesmas Sukarahayu Subang Tahun 2019.

\begin{tabular}{|c|c|c|c|c|c|}
\hline Klasifikasi Biaya & \multicolumn{2}{|c|}{ Tarif } & Cost Driver & \multicolumn{2}{|r|}{ Total } \\
\hline \multicolumn{6}{|l|}{ Unit Level Activity Cost } \\
\hline Biaya Jasa Perawat & $\mathrm{Rp}$ & 41.495 & 4725 & $\mathrm{Rp}$ & 196.061.861 \\
\hline Air & $\mathrm{Rp}$ & 279 & 4725 & $\mathrm{Rp}$ & 1.317 .500 \\
\hline Listrik & $\mathrm{Rp}$ & 2.125 & 30.300 & $\mathrm{Rp}$ & 64.382 .973 \\
\hline \multicolumn{6}{|l|}{ Batch Relate Activity Cost } \\
\hline Kebersihan & $\mathrm{Rp}$ & 5.503 & 4725 & $\mathrm{Rp}$ & 26.000 .000 \\
\hline Bahan Habis Pakai & $\mathrm{Rp}$ & 36.456 & 2211 & $\mathrm{Rp}$ & 80.604 .000 \\
\hline Administrasi & $\mathrm{Rp}$ & 137.000 & 737 & $\mathrm{Rp}$ & 100.969 .000 \\
\hline \multicolumn{6}{|l|}{ Cost } \\
\hline Loundry & $\mathrm{Rp}$ & 2.116 & 4725 & $\mathrm{Rp}$ & 10.000 .000 \\
\hline Penyusutan Gedung & $\mathrm{Rp}$ & 267.320 & 3672.00 .00 & $\mathrm{Rp}$ & 40.900 .000 \\
\hline Penyusutan Fasilitas & $\mathrm{Rp}$ & 2.540 & 4725 & $\mathrm{Rp}$ & 12.000 .000 \\
\hline \multicolumn{4}{|l|}{ Total Biaya } & $\mathrm{Rp}$ & 532.235 .334 \\
\hline \multicolumn{4}{|c|}{ Jumlah hari pasien rawat inap } & & 4725 \\
\hline \multicolumn{4}{|c|}{ Tarif Rawat Inap } & $\mathrm{Rp}$ & 112.642 \\
\hline
\end{tabular}

Sumber: Data yang telah diolah

Dari perhitungan di atas tabel 3, dapat diketahui bahwa hasil perhitungan tarif jasa rawat inap dengan menggunakan metode Activity Based Costing Rp. 112.642. Dari hasil tersebut, jika di bandingkan dengan tarif yang berlaku saat ini dipuskesmas sesuai dengan tarif dari pemerintah daerah kabupaten subang sebesar Rp. 162.000, maka Activity Based Costing memberikan hasil yang 
lebih kecil sehingga terdapat selisih untuk tarif rawat inap $\mathrm{Rp} 49.358$ dari tarif yang telah ditentukan. Berdasarkan hasil yang di lakukan perhitungan dengan metode activity based costing menunjuk hasil yang lebih rendah di bandingan dengan tarif yang berlaku di Puskesmas Sukarahayu Subang.

\section{PEMBAHASAN}

Penentuan tarif rawat inap menggunakan Activity Based Costing System berdasarkan dokumen yang peneliti dapatkan dari pihak puskesmas. Aktivitas - aktivitas tersebut dikelompokkan menjadi beberapa pusat aktivitas, yaitu :

1. Aktivitas Perawatan Pasien, yang terdiri atas jasa perawat.

2. Aktivitas Pemeliharaan Inventaris, yang terdiri atas; biaya depresiasi gedung, biaya depresiasi peralatan, dan biaya cleaning service.

3. Aktivitas Pelayanan Pasien, yang terdiri atas biaya konsumsi.

4. Aktivitas Pelayanan Pasien, yang terdiri atas; biaya air dan listrik, biaya administrasi, biaya bahan habis pakai, dan biaya laundray.

Berikut dijelaskan mengenai elemen-elemen biaya diatas :

1. Biaya jasa perawat dalam hubungannya dengan penetapan tarif kamar rawat inap, biaya ini secara tidak langsung ikut mempengaruhi aktivitas bagian rawat inap, maka aktivitas ini termasuk dalam katagori unit level activity cost. Untuk itu biaya sebesar Rp. 196.061.861. dialokasikan untuk setiap pasien rawat inap.

2. Biaya Listrik rawat inap puskesmas memerlukan tenaga listrik untuk menjalankan perlatan eletronik, untuk penerangan atau fasilitas yang ada. Biaya yang dikeluarkan berkaitan dengan listrik sebesar Rp. 64.382.973. biaya untuk penggunaan listrik dan air termasuk katogori unit level activity cost, karena biaya selalu berubah sesuai dengan pemakaian atau perubahan KWH kamar yang terpakai. Fasilitas yang menggunakan tenaga listrik meliputi televisi, lampu, lemari es, AC, kipas angin.

3. Biaya Air rawat inap puskesmas memerlukan air untuk mandi dan kegiatan lainnnya. Biaya yang dikeluarkan sebesar Rp.1.317.500

4. Biaya Administrasi Pelayanan administrasi diberikan untuk menunjang kelancaran dalam penyediaan aktivitas sarana dan prasarana. Biaya administrasi yang dikeluarkan sebesar Rp. 100.969.000 termasuk kategori batch related activity based costing.

5. Biaya bahan habis pakai Biaya habis bahan habis pakai adalah biaya yang digunakan oleh perawat untuk pasien selama pasien dalam perwatan di rumah sakit. Besarnya biaya bahan habis pakai sebesar Rp.80.604.000

6. Biaya laundray Aktivitas yang dilakukan untuk menyediakan layanan bersih kepada pasien rawat inap seperti seprai, selimut, korden, sarung bantal. Biaya laundrai sebesar Rp 10.000 .000

7. Biaya Cleaning Service Biaya cleaning service atau biaya kebersihan adalah biaya yang dikeluarkan oleh puskesmas untuk menunjang kebersihan lingkungan rawat inap dan demi kenyamanan pasien dan keluarga pasien, sehingga pasien merasa nyaman dan tenang. Biaya ini termasuk dalam kategori batch related activity cost. Besarnya biaya cleaning service Rp.26.000.000

8. Biaya Depresiasi Gedung Biaya penyusutan bangunan puskesmas sebesar Rp.40.900.000.

9. Biaya Depresiasi Fasilitas Pembebanan Penyusutan fasilitas. Penyusutan puskesmas sebesar Rp 12.000.000 yang terdiri dari penyusutan televise, AC, kulkas, bed dan kipas angin dan lain-lain.

Setelah aktivitas-aktivitas ini diidentifikasi sesuai dengan kategorinya, langkah selanjutnya adalah mengidentifikasi cost driver dari setiap biaya aktivitas. Pengidentifikasian ini dimasukan dalam penentuan kelompok aktivitas dan tarif atau cost driver. Dari hasil pembahasan, dapat diketahui bahwa hasil perhitungan tarif jasa rawat inap dengan menggunakan activity based costing Dari hasil tersebut, jika dibandingkan dengan tarif yang ada, maka metode activity based costing memberi hasil yang lebih kecil.

Dengan diketahui tarif jasa maka dapat mengetahui kebutuhan di puskesmas yang langsung berhubungan dengan unit pelayanan jasa rawat inap. Maka dapat dilihat tarif jasa rawat inap menggunakan metode activity based costing menjadi bahan evaluasi dan pertimbangan untuk 
pengambilan keputusan sehingga penentuan tarif lebih efektif. Dilihat dari data komponen kebutuhan operasional pada puskesmas mengalami kenaikan rata-rata kunjungan di awal bulan tahun 2019 mengalami kenaikan, pertengahan bulan mengalami penurunan. Dan awal bulan September mengalami kenaikan, namun diakhir tahun mengalami penurunan Kembali.

\section{KESIMPULAN}

Berdasarkan hasil dan pembahasan mengenai tarif rawat inap pada puskesmas sukarahayu subang dapat disimpulkan bahwa puskesmas sukarahayu kabupaten Subang dalam menarik imbalan atau jasa yang diberikan kepada masyarakat menggunakan tarif rawat inap yang tercantum dalam peraturan daerah kabupaten subang berdasarkan perhitungan yang telah dilakukan dapat diketahui tarif rawat inap untuk pasien pada puskesmas sesuai dengan pelayanan yang telah di berikan oleh puskesmas Sukarahayu Subang. Dari hasil perhitungan dengan menggunakan metode Activity Based Costing dibandingkan dengan tarif yang telah ditentukan oleh puskesmas sukarahayu berdasarkan perhitungan metode Activity Based Costing adalah Rp. 112.642. Sedangkan tarif yang berlaku saat ini dipuskesmas Rp. 162.000. Sehingga terdapat selisih $\mathrm{Rp} 49.358$ dari tarif yang telah ditentukan.

Bersumber pada hasil penelitian ini dikemukan implikasi secara teoritis serta praktis.

a. Implikasi Teoritis

Activity Based Costing ialah metode yang mempraktikkan konsep- konsep akuntansi aktivitas untuk menghasilkan perhitungan harga pokok ataupun tarif jasa rawat inap pada pengunjung puskesmas yang lebih akurat. Dalam penentuan tarif jasa pelayanan, penentu kebijakan secara teliti mengenali tujuan dari penentuan tarif tersebut. Tujuan ini dipergunakan sebagai salah satu pedoman kerja, sehingga puskesmas hendak bertahan hidup (survival), Menjadikan puskesmas bidang pelayanan kesehatan yang paling diminati, lebih bisa berkonsentrasi pada kenaikan pelayanan, mempertahankan loyalitas pelanggan lama serta mencari baru. Secara perspektif nilai tersebut diharapkan dapat memiliki energi terhadap kemandirian puskesmas, sebab perhitungan lebih riil ke arah aktivitas jumlah kunjungan, sehingga dapat mempermudah perhitungan kebutuhan operasional puskesmas.

b. Implikasi praktis

Penelitian ini digunakan sebagai masukan dalam penentuan tarif rawat inap yaitu dengan menganalisis penerapan yang digunakan menggunkan metode Activity Based Costing pada setiap aktivitas biaya-biaya diketahui secara akurat. Dan untuk mempertimbangkan faktorfaktor yang dapat mempengaruhi dalam penentuan tarif pelayanan rawat inap.

\section{REFERENSI}

Ali, P. bahjuri, Siahaan, renova glorya montesori, Solikha, dewi amila, \& Wikanestri, I. (2018). Penguatan Pelayanan Kesehatan Dasar di Puskemas. In Direktorat Kesehatan dan Gizi Masyarakat.

https://www.bappenas.go.id/files/1715/3974/8326/Buku_Penguatan_Pelayanan_Kesehatan_Das ar_di_Puskesmas-_Direktorat_Kesehatan_dan_Gizi_Masyarakat_Bappenas.pdf

Charter, W., \& Milton F, U. (2006). Akuntansi Biaya. Salemba Empat.

Datar, S. M., \& Rajan, M. V. (2017). Horngren's cost accounting : a managerial emphasis. https :// www .hbs.edu/faculty/Pages/item.aspx?num=53893

Garison, Noren, dan B. (2013). Akuntansi Manajerial (Edisi 14). Salemba Empat.

Gondodiputro, S. (2015). Kesiapan Puskesmas dalam Mendukung Jaminan Kesehatan Nasional Tahun 2019. Jurnal Sistem Kesehatan, 1(1), 12.

Hansen, D. R., \& Mowen, M. M. (2006). Cost Managment Accounting \& Control. In Manager.

Horngren, Datar, Foster, G. (2013). Akuntansi Biaya dengan Penekanan Manajerial (keduabelas). Erlangga . 
Krismiaji, A. y. (2015). Akuntansi Manajemen. Edisi Kedua. Yogyakarta: UPP AMP YKPN.

Mcgraw-hill, W. (2012). Managerial Accounting 14E-Garrison, Noreen\& Brewer.

Mowen, H. \&. (2004). Manajemen Biaya. In Manajemen Biaya.

Mulyadi. (2001). edisi 3. Akuntansi manajemen, Konsep, Manfaat, dan Rekayasa. In Universitas Gadjah Mada.

Mulyadi. (2009). Akuntansi Biaya (Edisi 14). Salemba Empat.

Sabijono, H., \& Panekenan, I. (2014). Penerapan Metode Activity Based Costing Dalam Menentukan Besarnya Tarif Jasa Inap Pada Penginapan Vili Calaca Manado. Jurnal Riset Ekonomi, Manajemen, Bisnis Dan Akuntansi, 2(2), 1417-1428.

Sumamora, H. (2012). Akuntansi Manajemen (Edisi 3). CV. Diandra Primamita Media.

Uma Sekaran \& Bougie. (2013). Research Method for Business: A skill Building Approach, 6th edition.Wiley\&Son Ltd. In United States: John Wiley \& Sons Inc.

Wensen, C. R., Manossoh, H., \& Pinatik, S. (2016). Penerapan Metode Process Costing System Dalam Penentuan Harga Pokok Produksi Pada Pt. Conbloc Indonesia Surya. Going Concern: Jurnal Riset Akuntansi, 11(3), 1-10. https://doi.org/10.32400/gc.11.3.13089.2016

Zakhra, A., \& Khusairi, K. (2019). Analisis Penentuan Biaya Pelayanan Pasien Rawat Inap Pada Puskesmas Palengaan Pamekasan. Aktiva: Jurnal Akuntansi Dan Investasi, 4 (1), 35-44. https :// doi.org/10.35835/aktiva.v4n1.03 